HEALTH SCIENCES

\title{
Hancornia speciosa serum fraction latex stimulates the angiogenesis and extracellular matrix remodeling processes
}

\author{
PATRÍCIA L. D'ABADIA, ELISA FLÁVIA LUIZ C. BAILÃO, RUY S. LINO JÚNIOR, \\ MATHEUS GABRIEL OLIVEIRA, VINICIUS B. SILVA, LEANDRA A.R. OLIVEIRA, \\ EDEMILSON C. CONCEIÇÃO, PAULO ROBERTO MELO-REIS, LEONARDO LUIZ \\ BORGES, PABLO JOSÉ GONÇALVES \& LUCIANE M. ALMEIDA
}

\begin{abstract}
The Hancornia speciosa latex reveals angiogenic, osteogenic, and antiinflammatory properties, which present its potential for developing of wound healing drugs; however, the latex compounds responsible for angiogenesis remain unknown. One strategy to screen these active compounds is evaluation of latex fractions. This study aimed to obtain different fractions of latex and evaluate its angiogenic activity separately using the chick chorioallantoic membrane (CAM) assay. The serum (SE) fraction was responsible for angiogenesis, which was subject to biochemical characterization and computational simulations in order to understand the contribution of $\mathrm{H}$. speciosa latex in wound healing process. Our results revealed weak antioxidant potential and absence of antimicrobial activity in the SE fraction. Phytochemical analysis identified chlorogenic acids (CGA) as the main compound of SE fraction. CGA bioactivity predictions identify different molecules associated with extracellular matrix (ECM) remodeling, such as metalloproteinases, which also are overexpressed in our CAM assay experiment. Docking simulations revealed the interactions between CGA and matrix metalloproteinase 2. In conclusion, SE latex fraction stimulates angiogenesis and may influence ECM remodeling. These properties may contribute to the wound healing process, and also confirm the widespread use of this plant.
\end{abstract}

Key words: chlorogenic acid, chronic wounds, docking simulations, mangabeira, secondary metabolites.

\section{INTRODUCTION}

The wound healing process is a physiological reaction to damaged tissues (Wallace \& Bhimji 2017). This is a complex process that may require several months for complete skin recovery. Besides, perturbation or delay in this process may lead to chronic or non healing wounds. The chronic wounds affect numerous people worldwide, and several cases lack effective treatment (Moghadam et al. 2017). Therefore, desirable strategy to accelerate this process needs to be developed.

The wound healing process can be divided into four phases that can overlap in time and space: hemostasis, inflammation, tissue formation, and tissue remodeling (Majewska \& Gendaszewska-Darmach 2011). A crucial step during the tissue formation process is the angiogenesis (Ibrahim et al. 2017). Specifically, in healing process, angiogenesis involves the growth of new capillaries to form granulation 
tissue (Honnegowda et al. 2015). Another important step during wound healing is the extracellular matrix (ECM) remodeling that is damaged due to the lesion (Xue \& Jackson 2015). Recently, the identification of biomaterials that stimulate angiogenesis and/or ECM remodeling has received immense attention.

In this scenario, plant-derived compounds play an important role in drug development as exemplified by Biocure ${ }^{\circledast}$ and Regederm ${ }^{\oplus}$; these compounds are mainly composed of natural rubber latex, and stimulate angiogenesis and granulation tissue growth, thereby accelerating the wound healing process (Pelenova Biotechnology SA, http://www.pelenova.com. br). Some scientific studies have reported the excellent potential of natural rubber latex in tissue replacement and regeneration (Floriano et al. 2014, 2016, de Almeida et al. 2015, Moura et al. 2014, Araújo et al. 2012, Ereno et al. 2010); however, few studies have reported about allergy toward latex-based rubber products (Kelly \& Sussman 2017). Accordingly, our research group has been studying the latex of other plant species with potential angiogenic activity (Almeida et al. 2019, Floriano et al. 2016, Almeida et al. 2014, Melo-Reis et al. 2010).

In particular, we assumed that the Hancornia speciosa Gomes latex presents biotechnological potential in developing drugs for wound healing process. H. speciosa, popularly known as Mangabeira, is a tree belonging to Apocynaceae family, found in Brazilian Cerrado biome (Almeida et al. 2016). Ethnobotanical surveys have reported the traditional use of $H$. speciosa, in particular the milky juice of the fruit and trunk latex, for treating skin diseases, acne, warts, fungal diseases, tuberculosis, gastric ulcers, and bone fractures (Pott \& Pott 1994, Neto \& Morais 2003, Macedo \& Ferreira 2004, Sampaio \& Nogueira 2006, Santos et al. 2007). Moreover, an ethnopharmacological study reported that $H$. speciosa root can be used in wound-healing treatment (Hirschmann \& Arias 1990). In addition to the ethnobotanical knowledge, different pharmacological activities have already been described for $H$. speciosa latex in the scientific literature that highlight the angiogenic, osteogenic, and anti-inflammatory properties of this compound (Marinho et al. 2011, Floriano et al. 2016, Dos Santos Neves et al. 2016, Almeida et al. 2014). Besides the functional activity, the $H$. speciosa latex revealed absence of toxicity in different bioassays (Ribeiro et al. 2016, Almeida et al. 2014).

It is known that plants produce various secondary compounds as natural protection against microbial and insect attack. Some of these compounds can also be used to improve human health (Sun et al. 2015, Galati \& O'Brien 2004). Recently, the potential effectiveness of secondary metabolites in the prevention or attenuation of skin disorder symptoms and reduction in the healing time has been reported (Wittenauer et al. 2015, Danciu et al. 2015, Karim et al. 2014). Considering H. speciosa latex, the biological compounds responsible for the angiogenesis and/or ECM remodeling remain unknown. We used latex fractionation to initiate the screening of these active compounds.

Thus, this study aimed to obtain different fractions of $H$. speciosa latex and evaluate its angiogenic activity separately, using the chick chorioallantoic membrane (CAM) assay. Our results revealed that the compounds responsible for the angiogenic activity are present in the serum (SE) fraction of $H$. speciosa latex. Moreover, the SE fraction was subjected to others assays in order to evaluate the antibacterial and antioxidant potentials, which is an important aspects during wound healing. After evaluating the biological activity, the SE fraction was subjected to an initial phytochemical screening accompanied by the most accurate search, 
using high performance liquid chromatography (HPLC), which identified the chlorogenic acid (CGA) as the main compound in SE. To evaluate the potential of CGA during wound healing process we initially performed a computational prediction. Different computational methods have been used to study the drug discovery process targeting protein and other molecular interactions (Gfeller et al. 2013, Liu et al. 2010). Thus, we also evaluated the biological activity spectrum of CGA with application of in silico tools, including target prediction and docking simulations.

\section{MATERIALS AND METHODS}

\section{Latex extraction}

The latex of $H$. speciosa was collected from Universidade Estadual de Goiás tree collection, in the city of Ipameri, (State of Goiás - Brazil). A voucher specimen was deposited at the Herbarium of Universidade Estadual de Goiás, Anápolis, Goiás, Brazil, under code number 4875. The latex was collected in a sterile container by drilling in the tree trunk (Arruda et al. 2016).

\section{Hancornia speciosa latex fractionation}

$H$. speciosa latex was centrifuged at $4{ }^{\circ} \mathrm{C}$ for 1 $\mathrm{h}$ at $22.000 \mathrm{~g}$ (Heraeus Megafuge 16R, Thermo Scientific). After centrifugation, the rubber was carefully separated, and a new centrifugation was performed to remove any phase contaminants. After latex centrifugation is possible to obtain two different fractions: 1) the top white zone with the rubber particles (called in this article as RU); and 2 ) the serum layer containing large variety of proteins and luteoids compounds (called in this article as SE).

\section{Angiogenic potential/CAM assay}

This study was approved by the Ethics Committee on the use of animals at the Universidade
Estadual de Goiás, Brazil (Protocol no007/2016). The CAM model was used to evaluate the angiogenic activity based on a methodology adapted from Melo-Reis et al. 2010. In total, 100 fertile chicken eggs (Gallus domesticus), divided in 5 groups, were incubated at $37^{\circ} \mathrm{C}$ in a humidified atmosphere $(60-70 \%$ relative humidity). On the fifth day of incubation, a circular hole was created at the large end of the eggshell (2-3 cm diameter), the eggshell membrane was removed, and the eggs were kept in the incubator. Sterilized filter paper disks ( $0.5 \mathrm{~cm}$ diameter) were soaked in $3 \mu \mathrm{L}$ of the following solutions: (1) rubber fraction (RU); (2) serum fraction (SE); (3) Regederm ${ }^{\oplus}$ commercial product from Pele Nova Biotecnologia, stimulates angiogenesis and is prepared with Hevea brasiliensis latex (RE, angiogenesis enhancer); (4) water (WA, negative control); and (5) dexamethasone (DE, angiogenesis inhibitor). The filter paper disk was placed directly in contact with the CAM membrane. The selected area of contact included vein of greater caliber visible through the opening made in the eggshell. Thereafter, the egg holes were sealed with a sterilized tape and the eggs were incubated for another 72 h. Subsequently, the angiogenic response was evaluated by comparing the percentage of vascularization around the filter paper disks. CAMs were fixed in formaldehyde solution (3.7\%) for $5 \mathrm{~min}$, cut with curved blunt scissors, and were maintained in Petri dishes containing formaldehyde solution.

\section{CAM morphometric evaluation}

The morphometric analysis was performed with fresh CAM of 20 eggs from each group. The membranes were placed in a Petri plate and photographed in a stereoscope (Bioptika) with increase of $30 \times$. Analysis and quantification of newly-formed vascular nets was carried out through the captured images. The area of 
each assay was determined using the programs Gimp for Windows (version 2.0.5) and Image J ( $\mathrm{NIH}$, version 1.28). The images were created in order to achieve a better resolution of the blood vessels, using saturation, light, and contrast, which were quantified in pixels. In order to analyze the angiogenic activity, the treated and control groups were compared using one way ANOVA on ranks, followed by Tukey's post-hoc test $(p<0.05)$.

\section{CAM histological evaluation}

The membranes were fixed in tamponed formalin, processed, blocked into paraffin, and were then sectioned into $5 \mu \mathrm{m}$ sections and stained using the hematoxylin and eosin (HE) stains. The images were captured in an optical microscope. For each treatment, five slides were evaluated. For each slide, different fields were randomly analyzed. Three parameters were evaluated: inflammation, presence of conjunctive cells, and angiogenesis. The results were visually classified according to the intensity, and the data were transformed into quantitative variables, by assigning the following scores: absent (0), discrete (1-25\%), moderate (25$50 \%$ ), and accentuated (above 50\%). Statistical analyses were performed using ANOVA, where $p$-values $<0.05$ were considered as indicative of significance. Dunn's test was used highlight the significant mean difference; and the results were expressed with alphabets. Similar alphabets indicated no significant difference.

\section{Gene expression evaluation}

CAM membranes exposed to different treatments were snap frozen in liquid nitrogen. The total RNA was extracted from each sample using the TRIzol reagent (TRI Reagent, Sigma- Aldrich, St. Louis, MO, USA). RNA integrity was analyzed via agarose gel electrophoresis and ethidium bromide staining. The total RNA concentration and quality was measured using the SpectraMax Paradigm from Molecular Devices. Total RNA samples were reverse-transcribed using the High Capacity RNA-to-cDNA kit (Applied Biosystems, Foster City, CA). The quantitative real-time polymerase chain reaction ( $\mathrm{R}$ RT-PCR) was performed using the SYBR Green PCR master mix (Applied Biosystems, Foster City, CA) in the Applied Biosystems Step One Plus PCR System (Applied Biosystems Inc.). The quantitative data was obtained using the transcript that encodes the 18S rRNA (KU939310) subunit as the endogenous control. The annealing temperature for all primers was $62{ }^{\circ} \mathrm{C}$. The qRT-PCR reaction was performed in triplicate for each cDNA sample, and a melting curve analysis was performed to confirm the single PCR products. The relative standard curve was generated using a pool of cDNAs from all the conditions that were used, which was serially diluted in a ratio of 1:5-1:3125. Relative expression levels of transcripts of interest were calculated using the standard curve method for relative quantification (Bookout et al. 2006). Student's $t$-test was applied in the statistical analyses ( $p$ $<0.05)$.

\section{Antimicrobial activity}

The antimicrobial activity of the SE fraction was determined by the agar diffusion method, according to the Clinical and Laboratory Standards Institute guidelines (CLSI 2017). The suspensions of Escherichia coli (ATCC 25312) and Staphylococcus aureus (ATCC 29231) were set at 0.5 of the McFarland scale (Silva et al. 2012), and subsequently inoculated on the surface of plates containing Mueller-Hinton agar. After inoculation, the paper discs were impregnated with gentamicin (control antimicrobial) and disks with $5 \mu \mathrm{l}$ of the SE fraction were added to the agar. Eventually, the plates were incubated at $36{ }^{\circ} \mathrm{C}$ for $24 \mathrm{~h}$ and the zones with complete 
growth inhibition were measured using a millimeter ruler. This assay was performed in duplicate.

\section{DPPH radical scavenging assay}

Scavenging of DPPH (2,2-diphenyl-1picrylhydrazyl) free radical was performed using discoloration method, according to the adapted method described by Sánchez-Moreno et al. (1998) in order to evaluate the antioxidant activity (AOA) of the SE fraction. The samples were diluted in the same solution resulting in the concentrations of 25-125 mg/ml. Furthermore, 0.1 $\mathrm{ml}$ of each solution was mixed with $3.9 \mathrm{ml}$ of a $60 \mu \mathrm{M}$ DPPH solution. After an incubation time of $30 \mathrm{~min}$ at room temperature, the absorbance values were measured at $515 \mathrm{~nm}$ (Asample). The blank was measured with methanol without DPPH (Ablank). The DPPH solution $(3.9 \mathrm{ml}$ ) and methanol $(100 \mu \mathrm{l})$ were used as the negative control (Acontrol). The scavenging activity of each solution was determined according to the following equation:

AOA was finally expressed as $I C_{50}$, which indicates the concentration $(\mathrm{mg} / \mathrm{ml})$ of the extract required to cause a $50 \%$ decrease in the initial content of the DPPH solution. The assays were performed in triplicate.

\section{Phytochemical screening}

The SE fraction was submitted to initial phytochemical qualitative reactions for usual plant secondary metabolites. The screening was performed for alkaloids (Bouchardat, Draggendorff and Mayer reaction), anthraquinones (Borntraeger reaction), coumarins ( $\mathrm{NaOH}$ reactions), flavonoids (cianidin and sulfuric acid reactions, A-1 and A-II), phenolic compounds (precipitation reaction with ferric chloride), and tannins (iron salts reaction, protein precipitation, B-1 and
B-II), using methodologies previously described (Costa 2001, Matos 1988, Matos \& Matos 1989).

\section{High Performance Liquid Chromatography (HPLC)}

HPLC profiles from SE fraction were obtained using a Waters Alliance e2695 chromatograph (Milford, MA, USA) equipped with a photodiode detector (DAD 2998), a degasser module, a quaternary pump, and an automatic injector. A Zorbax C18 column $(250 \times 4.6 \mathrm{~mm}, 5 \mu \mathrm{m})$ was used, as along with a guard column of the same stationary phase. Data was processed using Empower 2.0.

The mobile phase comprised of acetonitrile acidified with $0.2 \%$ phosphoric acid ( $/ \mathrm{v}$ ), methanol, and $0.05 \%$ phosphoric acid $(v / v)$ in water in different proportions. Mobile phase was filtered via a $0.45 \mu \mathrm{m}$ membrane (Millipore, MA, United States) and degassed for $20 \mathrm{~min}$ in an ultrasonic bath. The mobile phase flow rate was $1 \mathrm{~mL} \cdot \mathrm{min}^{-1}$. The column oven was set at 30 ${ }^{\circ} \mathrm{C}$. The samples were solubilized in methanol and filtered via a $0.22 \mu \mathrm{m}$ Millex ${ }^{\circledR}$ membrane (Millipore, MA, USA). The injection volume was $10 \mu \mathrm{L}$, and the experiments were performed in triplicate.

Compounds from the fraction were identified by comparison with the retention times and absorption spectra (190-400 nm) of the following reference compounds: quercetin, rutin, kaempferol, gallic acid, ellagic acid, epigallocatechin gallate, catechin hydrate and CGA; they were obtained from Sigma-Aldrich (St. Louis, MO, USA). These substances have been reported as constituents of the Apocynaceae family (Bastos et al. 2017, Boligon et al. 2015, Erharuyi et al. 2014)

\section{Prediction of chlorogenic acid biological activity}


Bioactivity for CGA was predicted using SwissTargetPredicition (Gfeller et al. 2013) and PharmMapper (Liu et al. 2010) online tools, where the 15 top-ranked activities for each method were selected for further analysis. For PharmMapper, the pharmacophore mapping was set only for human protein targets $(2,241)$. The advanced options were maintained as default. SwissTargetPredicition tool predicts the targets of a molecule using a combination of 2D and 3D similarity measures, which compare the molecule with literature ligands (Gfeller et al. 2013). In PharmMapper, the potential targets are identified by predicting of the spatial arrangement of features essential for a molecule to interact with a specific target receptor (Liu et al. 2010).

\section{Molecular docking}

Docking simulations with CGA and human matrix metalloproteinase 2 (MMP2) (PDB: 1QIB) were run using the Dockthor server (Magalhães et al.
2014). The calculations were performed inside a sphere of $7 \AA$ radius centered at the ZN atom for MMP2. The advanced options were maintained as default. The most energetically favorable conformation was selected for the analysis. Dockthor server is a grid based method that employs a multiple solution genetic algorithm and molecular force fields scoring function to predict the binding mode and affinity of a molecule within the binding site of the receptor target of interest (Magalhães et al. 2014).

\section{RESULTS}

\section{Angiogenic potential of Hancornia speciosa latex fractions}

Statistical analysis $(p<0.05)$ revealed that SE fraction exhibited a significant vascular net percentage increase when compared with both WA and DE controls (Fig. 1). In addition, no significant was observed among SE fractions of latex and the RE control ( $p>0.05)$. In contrast,
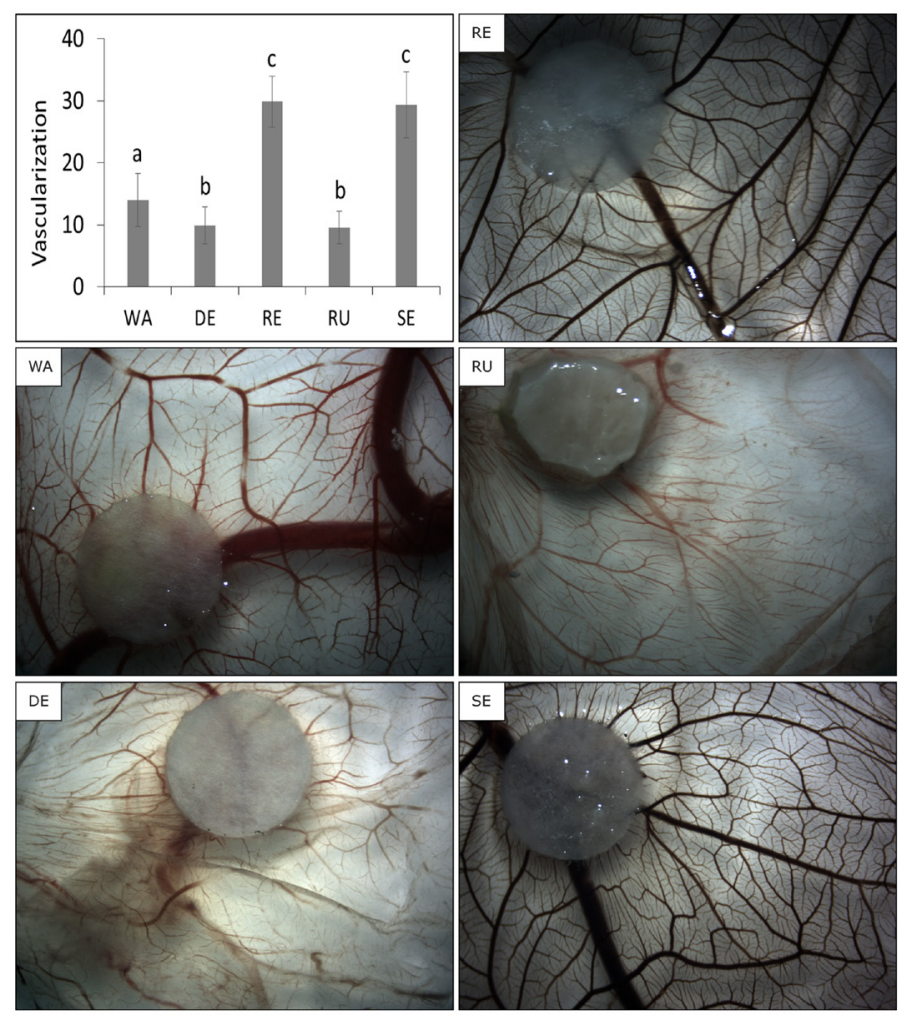

Figure 1. The vascular network in different controls and in the treatment using Hancornia speciosa latex fractions. The bars in the graphic represent the vascularization percentages average \pm SD for each treatment. The treatments were represented by: WA (water); DE (Dexamethasone ${ }^{\circ}$, angiogenesis inhibitor); RE (Regederm ${ }^{\circ}$, angiogenesis enhancer); RU (rubber fraction); and SE (serum fraction). The SE fraction showed a significant increase in the vascular network formed, compared to the neutral control and the inhibitor $(P<0.05)$, but between $S E$ fraction and positive control there was no significant difference $(P>0.05)$. Same letters means no significant statistical difference using the Tukey test comparision. 
the RU fraction exhibited high antiangiogenic activity did not differ significantly from the inhibitor DE (Fig. 1).

After morphological analysis, the CAMs were subjected to histological analysis (Fig. 2 and Table I). The results showed that SE fraction caused a significant increase in the inflammation, conjunctive cells and angiogenesis, when compared to the WA and DE. When compared with the RE, the SE fraction caused higher inflammation, and the conjunctive cells and angiogenesis rates increased. In addition, our data showed that the RU does not present angiogenic activity.
To confirm the angiogenic potential of the SE fraction, the CAMs were subjected to qRT-PCR and two genes associated with angiogenesis ( $\mathrm{mmp2}$ and vegf) were analyzed; the results obtained revealed that both genes were overexpressed in CAM subjected to the SE fraction (Fig. 3).

\section{Antibacterial potential of SE fraction}

Since the antibacterial activity is an important feature during the tissue regeneration process, the SE fraction was subjected to agar-well diffusion assay. The SE fraction did not present antibacterial activity against E. coli and S. aureus, and no inhibition zone was observed around SE sample disc (Fig. 4).

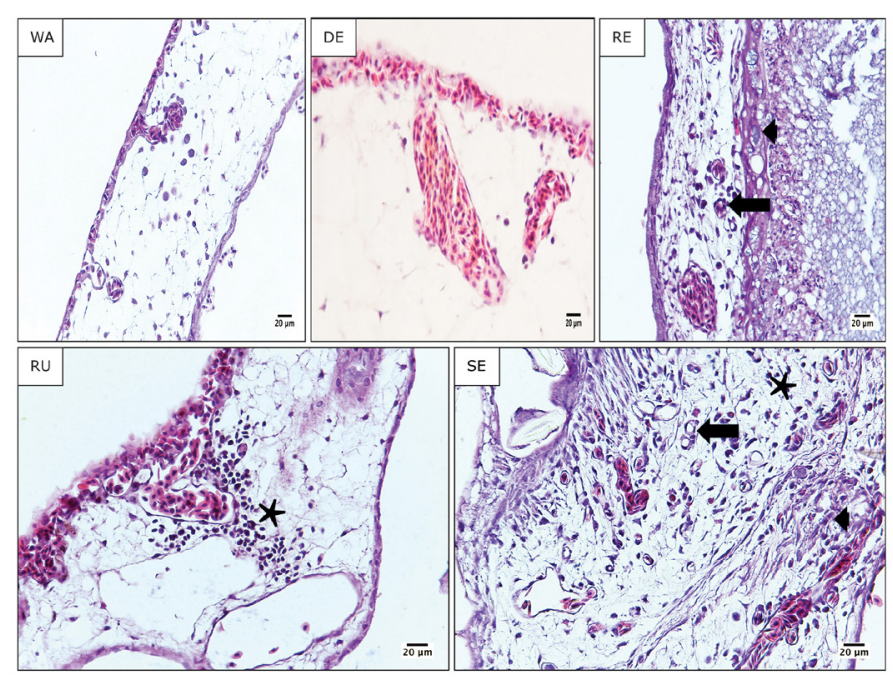

Figure 2. Histological analysis of chorioallantoic membranes CAMs treated with Hancornia speciosa latex fractions. Paraffin sections stained with hematoxylin-eosin for different groups: WA (water); DE (Dexamethasone ${ }^{\circledR}$, angiogenesis inhibitor); RE (Regederm ${ }^{\circledast}$, angiogenesis enhancer); RU (rubber fraction); and SE (serum fraction). The parameters analyzed were represented by: $(\Rightarrow)$ angiogenesis; $(\Delta)$ conjunctive cell; $\left(^{*}\right)$ inflammation.

Table I. Analysis of the histological parameters of chorioallantoic membranes (CAMs) treated with the control groups and fractions of Hancornia speciosa latex.

\begin{tabular}{|c|c|c|c|c|c|c|}
\hline \multirow{2}{*}{ TREATMENTS } & \multicolumn{2}{|c|}{ INFLAMMATION } & \multicolumn{2}{|c|}{ CONJUNCTIVE CELL } & \multicolumn{2}{|c|}{ ANGIOGENESIS } \\
\hline & Median & Dunn's test & Median & Dunn's test & Median & Dunn's test \\
\hline Water & 1 & A & 0 & $A$ & 0 & $A$ \\
\hline Dexamethasone $^{\circledast}$ & 0 & $A B$ & 0 & $A$ & 0 & $A$ \\
\hline Regederm ${ }^{\oplus}$ & 0.5 & $A$ & 0 & $A$ & 0.5 & $A$ \\
\hline Rubber & 1 & $A C$ & 0 & $A$ & 0 & $A$ \\
\hline SE & 2 & $A C$ & 2 & B & 2.5 & $\mathrm{~B}$ \\
\hline$P$ value & \multicolumn{2}{|c|}{$p=0.08$} & \multicolumn{2}{|c|}{${ }^{*} p<0.03$} & \multicolumn{2}{|c|}{${ }^{*} p=0.002$} \\
\hline
\end{tabular}

$P$ values of less than 0.05 were considered as indicative of significance ${ }^{*}$ ). Same letters represent no significant difference using Dunn's test. 


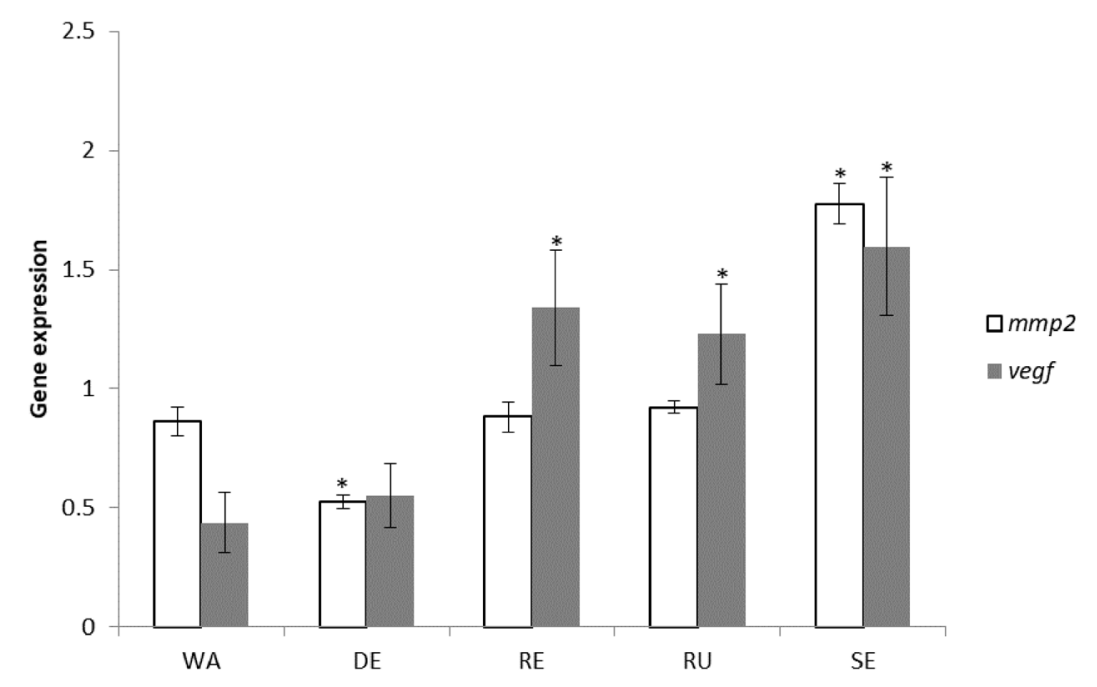

Figure 3. Expression levels of mRNA coding for MMP2 and VEGF evaluated by quantitative RT-PCR. WA (water); DE (Dexamethasone ${ }^{\circledR}$, angiogenesis inhibitor); RE (Regederm ${ }^{\circledR}$, angiogenesis enhancer); RU (rubber fraction); and SE (serum fraction). The asterisks denote values statically different from the neutral control group WA $(P<0.05)$. The results showed that $\mathrm{mmp2}$ and vegf genes were overexpressed in CAM treated with SE fraction.

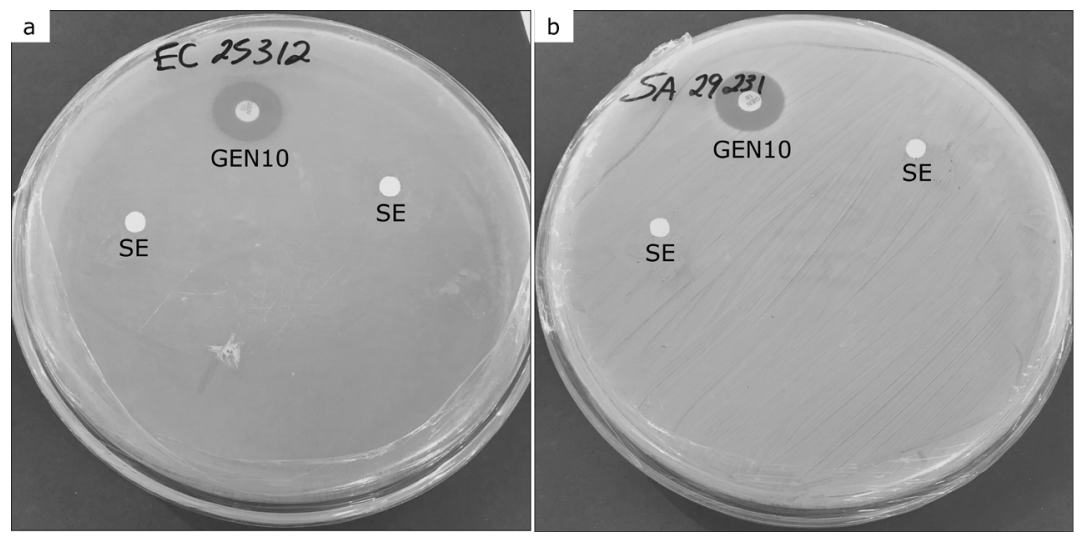

Figure 4. SE fraction of Hancornia speciosa latex presents no antibacterial activity against (a) Escherichia coli (ATCC 25312) and (b) Staphylococcus aureus (ATCC 29231). The bacterial samples were growth Mueller-Hinton agar for $48 \mathrm{~h}$ and the inhibition zones were measured using a millimeter ruler. Gentamicin (GEN10) was used as a positive antibacterial control.

\section{Antioxidant potential of SE fraction}

Using DPPH radical scavenging method, the $\mathrm{IC}_{50}$ of SE fraction $\left(I C_{50}=76.52 \mathrm{mg} / \mathrm{ml}\right)$ was compared with the $\mathrm{IC}_{50}$ from four different positive controls: butylated hydroxytoluene $\left(I C_{50}=0.20 \mathrm{mg} / \mathrm{ml}\right)$, butylated hydroxyanisole $\left(I C_{50}=0.09 \mathrm{mg} / \mathrm{ml}\right)$, tannic acid $\left(\mathrm{IC}_{50}=0.04 \mathrm{mg} / \mathrm{ml}\right)$, and ascorbic acid $\left(I C_{50}=0.09 \mathrm{mg} / \mathrm{ml}\right)$. Although the DPPH radical scavenging abilities of the SE fraction were less intense than the positive controls, this study showed that the SE fraction might serve as a free radical scavenger, presenting a weak antioxidant activity (Fig. 5).

\section{Phytochemical analysis of SE fraction}

Considering the biological activity of SE fraction, the presence of secondary metabolites in that fraction was evaluated. The presence of flavones, flavonols, flavanones, and tannins was observed; however, coumarins, alkaloids and anthraquinones were absent.

After the initial screening of secondary metabolites, the SE fraction was subjected to high performance liquid chromatography (HPLC), thus aiming to identify the main compounds present in this fraction. The main compound identified by HPLC was the CGA, an ester of caffeic acid and quinic acid. The presence of CGA in the SE fraction of $\mathrm{H}$. speciosa was confirmed by comparing its retention time and UV spectra (190-400 nm) with the standard (Fig. 6). 

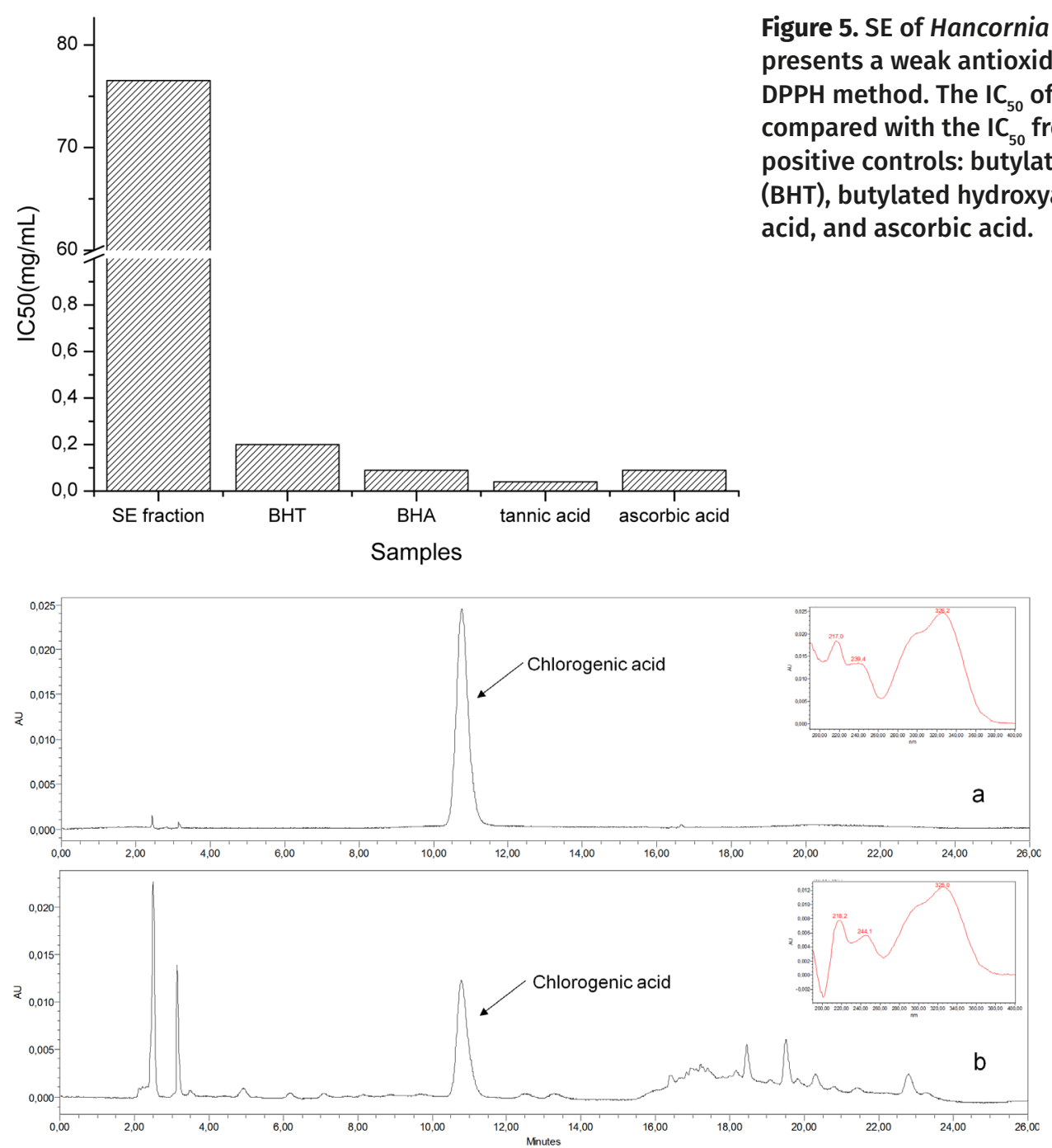

Figure 5. SE of Hancornia speciosa latex presents a weak antioxidant activity using DPPH method. The $\mathrm{IC}_{50}$ of SE fraction was compared with the $\mathrm{IC}_{50}$ from four different positive controls: butylated hydroxytoluene (BHT), butylated hydroxyanisole (BHA), tannic acid, and ascorbic acid.
Figure 6.

Chromatograms of chlorogenic acid (a, at $0.01 \mathrm{mg} / \mathrm{ml}$ ) and SE fraction of $H$. speciosa (b, at $500 \mathrm{mg} / \mathrm{ml}$ ), at $330 \mathrm{~nm}$. Insets show UV absorbance spectra (190-400 nm).

\section{Computational prediction of chlorogenic acid (CGA)}

The bioactivity prediction data of CGA revealed possible targets in humans, specifically those involved with anti-inflammatory, antineoplasic and angiogenisis processes (Table II). We highlighted the proteins with bioactivity associated with the wound healing process. The next computational evaluation included docking. For this analysis, we selected the key protein MMP2. MMPs are a growing family of metalloendopeptidases that cleave the protein components of the ECM and thereby play a pivotal role in tissue remodeling (Stamenkovic 2003).

Docking simulations between MMP2 and CGA revealed that CGA was capable of accommodating in the active site cavity of this enzyme by performing electrostatic and van der Waals interactions. In MMP2, the main interaction occurs with Glu-202 and Glu-210 residues through the hydrogen bonds. Other interactions were also observed with His-205, Ala-167, His-211, His-166, Ala-165, His-201, Val-198, Leu-164, Tyr-223, Pro-221, and Leu-163 residues (Fig. 7). 
Table II. Top-ranked bioactivity predicition data of chlorogenic acid using SwissTargetPredicition and PharmMapper tools.

\begin{tabular}{|c|c|c|}
\hline Rank & SwissTargetPredicition & PharmMapper \\
\hline $1^{\text {st }}$ & Aldo-keto reductase family 1 member B10 & Checkpoint kinase 1 \\
\hline $2^{\text {nd }}$ & Aldose reductase & Cholinesterase \\
\hline $3^{\text {rd }}$ & Aldo-keto reductase family 1 member B15 & $\begin{array}{l}\text { cGMP-specific 3,5-cyclic } \\
\text { phosphodiesterase }\end{array}$ \\
\hline $4^{\text {th }}$ & Alcohol dehydrogenase [NADP(+)] & Ribonuclease UK114 \\
\hline $5^{\text {th }}$ & 1,5-anhydro-D-fructose reductase & $\begin{array}{l}\text { Branched-chain-amino-acid } \\
\text { aminotransferase }\end{array}$ \\
\hline $6^{\text {th }}$ & Matrix metalloproteinase-2 * & $\begin{array}{l}\text { Tyrosine-protein phosphatase non- } \\
\text { receptor type } 1^{*}\end{array}$ \\
\hline $7^{\text {th }}$ & Matrix metalloproteinase-9 * & $\begin{array}{l}\text { Proto-oncogene tyrosine-protein kinase } \\
\text { Src }\end{array}$ \\
\hline $8^{\text {th }}$ & Matrix metalloproteinase-12 * & Kinesin heavy chain \\
\hline $9^{\text {th }}$ & Matrix metalloproteinase-13 * & $\begin{array}{l}\text { Galactosyl galactosyl xylosyl protein } \\
\text { 3-beta-glucuronosyltransferase } 1\end{array}$ \\
\hline $10^{\text {th }}$ & Matrix metalloproteinase-1 * & Macrophage migration inhibitory fator \\
\hline $11^{\text {th }}$ & Matrix metalloproteinase-3 * & Prothrombin* \\
\hline $12^{\text {th }}$ & Matrix metalloproteinase-10 * & $\begin{array}{l}\text { NAD-dependent malic enzyme, } \\
\text { mitochondrial }\end{array}$ \\
\hline $13^{\text {th }}$ & Matrix metalloproteinase-27 * & Carbonic anhydrase 2 \\
\hline $14^{\text {th }}$ & Matrix metalloproteinase-20 * & Glycogen synthase kinase-3 beta* \\
\hline $15^{\text {th }}$ & Tyrosyl-DNA phosphodiesterase 1 & Angiogenin* \\
\hline
\end{tabular}

* proteins whose activities are associated with wound healing process.

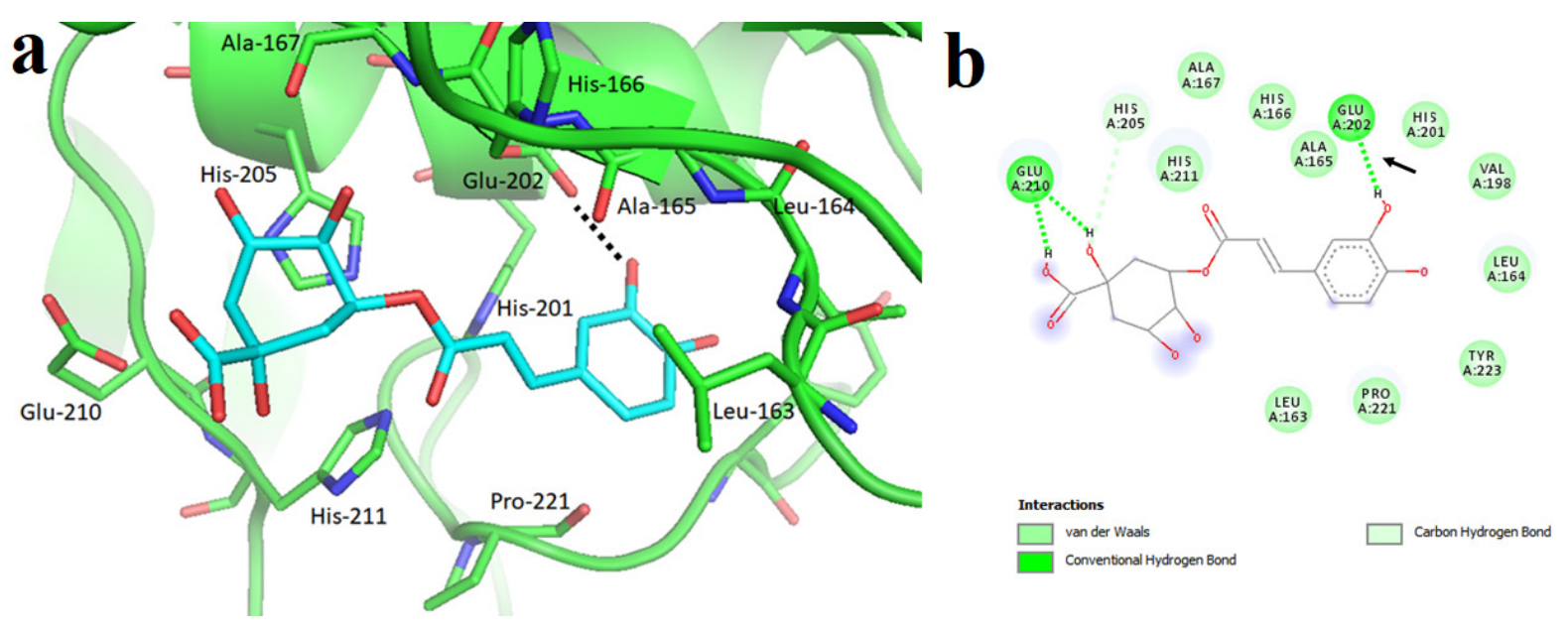

Figure 7. Predicted interaction between MMP2 and CGA. (a) Docking 3D model of CGA (carbon atoms in blue) within MMP2 active site, highlighting the main intermolecular interactions with protein residues. The interaction site is shown by the dotted line (---). (b) 2D interaction diagram between the CGA and MMP2 protein residues. The arrow shows the amino acid interactions $(\rightarrow)$. 


\section{DISCUSSION}

The stimulation of angiogenesis by plant compounds has attracted immense attention of the scientific community in recent years (Araújo et al. 2016). These substances can be used to accelerate the healing process because they are able to promote the growth and appearance of blood vessels in the damaged tissue (Chaves et al. 2016). This study investigated the angiogenic potential of the $H$. speciosa latex fractions in CAM in vivo model. We selected this method because it provides quick results, is cost-effective, simple, has high reproducibility, presents easy dynamic observation, and has minor ethical concerns (Nowak-Sliwinska et al. 2014, Aleksandrowicz \& Herr 2015). As a result, the H. speciosa SE fraction presented high angiogenic activity, and this potential was observed via morphological, histological and molecular analyses of CAM membranes exposed to latex.

In the morphological analyses, we observed that CAM treated with SE latex fraction presented significantly higher vessels count. In contrast, when CAM was treated with rubber latex fraction, angiogenesis was inhibited. Thus, the different fractions of $H$. speciosa latex present distinct angiogenic activity; the RU comprising cis-1.4-polyisoprene presents anti-angiogenic properties, and the SE fraction comprising secondary metabolites, enzymes, and luteoid compounds reveals angiogenic activity (Almeida et al. 2014).

Histological analysis revealed that angiogenesis, inflammation, and number of the conjunctive cell count were significantly higher in CAM treated with the SE fraction. The angiogenic and inflammation responses are linked in the healing wound, as the inflammatory cells secrete cytokines and growth factors to promote wound healing (May et al. 2008). Nevertheless, it important to remember that angiogenesis and inflammation are partially stimulated during the entire healing process. Angiogenesis needs to be stimulated in the inflammatory phase, whereas it needs to be prevented at the hemostasis stage (Ridiandries et al. 2018). A previous study reported that the $H$. speciosa crude latex exhibits significant anti-inflammatory activity via the inhibition of nitric oxide, prostaglandin E2, and cytokine production (Marinho et al. 2011); this anti-inflammatory action of the latex can be of interest in the hemostasis step. In contrast, the results observed in the present work indicate that the SE fraction can promote an initial increase in the inflammation and angiogenesis. Presumably, the components of $H$. speciosa latex can modulate angiogenesis and inflammation response during different steps of the wound healing process. In relation to the parameter conjunctive cells, the increase in the cell count is expected during the cell proliferation (Livezeanu et al. 2011).

In order to evaluate the molecular effects of $H$. speciosa latex in the angiogenesis process, mRNA expression of proangiogenic factors was analyzed. Expression levels of vegf and $\mathrm{mmp2}$ transcripts were compared to those detected in the control CAM. The treatment of CAM with $\mathrm{H}$. speciosa latex SE fraction promoted an increase in vegf and mmp2 expression. Despite various proangiogenic factors that may participate in various stages of angiogenesis, VEGF is considered to be the predominant and the most effective angiogenic mediator in human cutaneous wounds (Khanna et al. 2001). The action of VEGF during tissue repair process results in: (1) capillary permeability increase, which permits the arrival of inflammatory cells at injury site; and (2) migration and proliferation of preexisting endothelial cells (Galiano et al. 2004, Domingos et al. 2012). Other important angiogenesis process is the degradation of vascular basement membrane and remodeling 
of the ECM, in order to allow the endothelial cells to migrate and invade the surrounding tissues. This degradation is performed by a family of proteolytic enzymes called metalloproteases, including MMP2 (Hyldig et al. 2017).

Besides angiogenesis, protection of wounds against contaminating microorganisms is an important step in the wound healing process. The presence of microorganisms and their toxins in the wound can lead to an increased release of pro-inflammatory cytokines, prolonging the inflammation process. This prolongation may cause the wound to enter the chronic state, and therefore, it cannot be healed. In addition, during the wound healing process, there is an overproduction of reactive oxygen species that may decrease the rate of wound healing (Lodhi \& Singhai 2013). In this context, polyphenols have received significant attention due to their effectiveness in the attenuation of skin disorders and the reduction in healing time (Moghadam et al. 2017, Działo et al. 2016, Martinotti \& Ranzato et al. 2015). In a previous study, Geller et al. (2015) evaluated the wound healing potential of ethanolic extract of $H$. speciosa leaves and suggested that the secondary metabolites present in the leaves (quinic acid, bornesitol, and rutin) promote migration and/or proliferation of fibroblasts in an artificial wound, and therefore, these compounds may play a significant role in the wound healing process. In the present study, we identified the following polyphenol classes in the SE fraction: flavones, flavonols, flavanones and tannins. The most common properties of these classes of polyphenols are: antioxidant, anti-inflammatory, and antimicrobial. All these characteristics are crucial in the wound healing process.

Besides identification of flavones, flavonols, flavanones, and tannins, the SE fraction does not present any antimicrobial activity; moreover, it also presented a weak antioxidant activity
(Fig. 5). These results instigated our group to perform a more accurate analysis of the SE fraction. The CGA was identified by HPLC in the latex SE fraction (Fig. 6). CGAs are esters formed between caffeic and quinic acids, and represent an abundant group of plant polyphenols (Liang \& Kitts 2015). Evidence reveals that CGAs exhibit antioxidant, anti-mutagenic, and antiinflammatory activities and are able to modulate numerous important metabolic pathways (Liang \& Kitts 2015). The identification of CGA in SE fraction is in accordance with dos Santos Neves et al. (2016), who previously identified CGA in $H$. speciosa latex and suggested that CGA may contribute to the $H$. speciosa latex effects on bone regeneration (dos Santos Neves et al. 2016).

Over the past decades, in silico tools have been proven to be effective filters in predicting targets of small molecules; moreover, significant evidence reveals that several drugs elicit their therapeutic activities by modulating multiple targets (Sanders et al. 2012, Koutsoukas et al. 2011). Accordingly, we used $2 D$ and 3D similarity measures to compare CGA to a library of actives compounds (SwissTargetPrediction and PharmMapper). The results interestingly indicate that several CGA predicted targets [9 metalloproteinases (MMP 1, 2, 3, 9, 10, 12, 13, 20, and 27), angiogenin, prothrombin, and tyrosine-protein kinase] are associated with ECM remodeling and wound healing. In normal healing wounds process, the ECM directs an organized response characterized by the four phases of hemostasis, inflammation, proliferation, and remodeling (Clark 1993).

The metalloproteinases participate in the proteolytic degradation of the vascular basement membrane and remodelling of the ECM components during angiogenesis (Rundhaug 2005). It was demonstrated that CGA enhanced the capillary-like tube formation of endothelial cells in an in vitro angiogenesis 
assay and this effect was attributed to CGA regulation control over the secretion of collagens and MMPs (Moghadam et al. 2017). This data is in accordance with our qRT-PCR analysis, which presented an overexpression of $m m p-2$ in the presence of SE fraction latex.

Other in silico strategy adopted in the present research was the docking analysis. Molecular docking is the study that predicts the binding of two or more molecular structures, e.g., drug and enzyme or protein (Roy et al. 2015). We selected MMP2 for docking analysis as this protein was identified as a potential target for CGA by target prediction. MMP2 is a key protein implicated in wound healing because it degraded type IV collagen, which is fundamental for tissue organization (Moghadam et al. 2017).

Docking simulations revealed that CGA could carry out favorable intermolecular interactions within MMP2 active site (Fig. 7). The main interactions occur between CGA catechol moiety and Glu-202 in MMP2 active site, which is one of the main residues involved in the catalytic activity of this enzyme (Leonidas et al. 1999). Thus, in silico findings suggest that CGA present molecular characteristics that favorably to contribute to wound healing, thereby modulating multiple targets involved in this process.

\section{CONCLUSIONS}

The SE of $H$. speciosa latex possesses high angiogenic activity, weak antioxidant potential, and no antimicrobial activity in the examined strains. During the wound healing process, all these characteristics are important; however, the SE fraction mainly presents the angiogenic property. The responsible compounds for angiogenic activity could be secondary metabolites or enzymes present in the $H$. speciosa latex. In the present work, we identified CGA as the main secondary metabolite of the SE latex fraction. In silico analysis predicted metalloproteinases as CGA-targets, and the interaction between CGA and MMP2 was evaluated. The CGA appears to interact with the active site cavity of this metalloproteinase. Results suggest that CGA can regulate ECM remodeling and consequently stimulate the wound healing process. These conclusions were mainly based on the CAM assay model results and in silico predictions and therefore they should be confirmed in whole-animal studies and/or in the clinical protocols.

\section{Acknowledgments}

We would like to thank Mariana Telles and Osvaldo Pinto for technical support. We thank also the Brazilian funding agencies Conselho Nacional de Desenvolvimento Científico e Tecnológico (MCT/CNPq), FNDCT, Coordenação de Aperfeiçoamento de Pessoal de Nivel Superior (CAPES), Financiadora de Estudos e Projetos (FINEP) and FAPEG. LMA and EFLCB were supported by Universidade Estadual de Goiás with fellowships at the program PROBIP (Scientific Production Support Program); JCN and PJG were supported by CNPq productivity fellowships and ADLP was supported by CAPES student fellowship.

\section{REFERENCES}

ALEKSANDROWICZ E \& HERR I. 2015. Ethiccal eutanasia and short-term anestesia of chick embryo. ALTEX 32: 143-147.

ALMEIDA LM ET AL. 2014. Hancornia speciosa latex for biomedical applications: physical and chemical properties, biocompatibility assessment and angiogenic activity. J Mater Sci Mater Med 25: 2153-2162.

ALMEIDA LM, MAGNO LN, PEREIRA AC, GUIDELLI ÉJ, FILHO OB, KINOSHITA A \& GONÇALVES PJ. 2019. Toxicity of silver nanoparticles released by Hancornia speciosa (Mangabeira) biomembrane. Spectrochim Acta A Mol Biomol Spectrosc 5(210): 329-334.

ALMEIDA LM, NOGUEIRA CA, BORGES PP, PRADO ADL \& GONÇALVES PJ. 2016. State of the art of scientific on Hancornia speciosa: trends and gaps. Rev Bras Frutic 38(4): e-869. 
ARAÚJO LA, ARAÚJO RG, GOMES FO, LEMES SR, ALMEIDA LM, GONÇALVES PJ, MRUÉ F, SILVA-JÚNIOR NJ \& MELO-REIS PR. 2016. Physicochemical/photophysical characterization and angiogenic properties of Curcuma longa essential oil. An Acad Bras Cienc 88: 1889-1897.

ARAÚJO MM, MASSUDA ET \& HYPPOLITO MA. 2012. Anatomical and functional evaluation of tympanoplasty using a transitory natural latex biomembrane implant from the rubber tree Hevea brasiliensis. Acta Cir Bras 27: 566-571.

ARRUDA AS, FARIA RQ, PEIXOTO N, MOREIRA ASF, FLORIANO JF, GRAEFF CFO, GONÇALVES PJ \& ALMEIDA LM. 2016. Magabeira latex production evaluation in Cerrado region of Goiás. Cienc Florest 26(3): 939-948.

BASTOS KX, DIAS CN, NASCIMENTO YM, SILVA MS, LANGASSNER SMZ, WESSJOHANN LA \& TAVARES JF. 2017. Identification of phenolic compounds from Hancornia speciosa (Apocynaceae) leaves by UHPLC orbitrap-HRMS. Molecules 22: 143.

BOLIGON AA ET AL. 2015. HPLC analysis and antimicrobial, antimycobacterial and antiviral activities of Tabernaemontana catharinensis A. DC. J Appl Biomed 13: 7-18.

BOOKOUT AL, CUMMINS CL, MANGELSDORF DJ, PESOLA JM \& KRAMER MF. 2006. High-throughput real-time quantitative reverse transcription PCR. Cur Protoc Mol Biol Chapter 15, Unit 1518.

CHAVES DA, LEMES SR, ARAÚJO LA, SOUSA MAM, FREITAS GB, LINO-JÚNIOR RS, MRUÉ F \& MELO-REIS PR. 2016. Angiogenic activity of the aqueous solution of Barbatimão (Stryphnodendron adstringens). Rev Bras Pla Med 18: 524-530.

CLARK RA. 1993. Biology of dermal wound repair. Dermatol Clinics. 11: 647-666.

CLSI. 2017. Performance Standards for Antimicrobial Susceptibility Testing. $27^{\text {th }}$ ed., CLSI supplement M100. Wayne, PA: Clinical and Laboratory Standards Institute; 2017.

COSTA AF. 2001. Farmacognosia, 3 ed. F. Calouste Gulbenkian, Lisboa.

DANCIU C ET AL. 2015. Evaluation of phenolic profile, antioxidant and anticancer potential of two main representants of Zingiberaceae family against B164A5 murine melanoma cells. Biol Res 48: 1-9.

DE ALMEIDA LM, PRADO ADL, D'ABADIA PL, MACHADO KB, MELOREIS PR, NABOUT JC \& GONÇALVES PJ. 2015. The state-of-art in angiogenic properties of latex from different plant species. Current Angiogenesis 4(1): 10-23.
DOMINGOS ALA, GARCIA SB, BESSA JR J, CASSINI MF, MOLINA CAF \& TUCCI JUNIOR S. 2012. Expression of VEGF and collagen using a latex biomembrane as bladder replacement in rabbits. Int Braz J Urol 38: 536-543.

DOS SANTOS NEVES J, FRANCHIN M, ROSALEN PL, OMAR NF, DOS SANTOS MA, PASCHOAL JA \& NOVAES PD. 2016. Evaluation of osteogenic potential of Hancornia speciosa latex in rat calvaria and its phytochemical profile. J Ethnopharmacol 13(183): 151-158.

DZIAŁO M, MIERZIAK J, KORZUN U, PREISNER M, SZOPA J \& KULMA A. 2016. The potential of plant phenolics in prevention and therapy of skin disorders. Int J Mol Sci 17: 160.

ERENO C, GUIMARÃES SAC, PASETTO S, HERCULANO RD, SILVA CP, GRAEFF CFO, TAVANO O, BAFFA O \& KINOSHITA A. 2010. Latex use as an occlusive membrane for guided bone regeneration. J Biomed Mat Res Part A 95A: 932-939.

ERHARUYI O, FALODUN A \& LANGER P. 2014. Medicinal uses, phytochemistry and pharmacology of Picralima nitida (Apocynaceae) in tropical diseases: A review. Asian Pacific J Trop Med 7: 1-8.

FLORIANO JF, MOTA LSLS, FURTADO EL, ROSSETTO VJV \& GRAEFF CFO. 2014. Biocompatibility studies of natural rubber latex from different tree clones and collection methods. J Mat Sci Mat Med:10.1007/s10856-013-5089-9.

FLORIANO JF ET AL. 2016. Comparative study of bone tissue accelerated regeneration by latex membranes from Hevea brasiliensis and Hancornia speciosa. Biomedical Physics Engeering Express 2: 045007.

GALATI G \& O'BRIEN PJ. 2004. Potential toxicity of flavonoids and other dietary phenolics: significance for their chemopreventive and anticancer properties. Free Radic Biol Med 37: 287-303.

GALIANO RD, TEPPER OM, PELO CR, BHATT KA, CALLAGHAN M, BASTIDAS N, BUNTING S, STEINMETZ HG \& GURTNER GC. 2004. Topical vascular endothelial growth factor accelerates diabetic wound healing through increased angiogenesis and by mobilizing and recruiting bone marrow-derived cells. Am J Pathol 164(6): 1935-1947.

GELLER FC, TEIXEIRA MR, PEREIRA AB, DOURADO LP, SOUZA DG, BRAGA FC \& SIMÕES CM. 2015. Evaluation of the wound healing properties of Hancornia speciosa leaves. Phytother Res 29: 1887-1893.

GFELLER D, MICHIELIN O \& ZOETE V. 2013. Shapping the interaction lasdscape of bioactive molecules. Bionformatics 29: 3073-3079.

HIRSCHMANN GS \& ARIAS AR. 1990. A survey of medicinal plants of Minas Gerais. Brazil. J Ethnopharmacol 29: 159-172. 
HONNEGOWDA TM, KUMAR P, UDUPA EG, KUMAR S, KUMAR U \& RAO P. 2015. Role of angiogenesis and angiogenic factors in acute and chronic wound healing. Plast Aesthet Res 2: $243-249$.

HYLDIG K, RIIS S, PENNISI CP, ZACHAR V \& FINK T. 2017. RevieW implications of extracellular matrix production by adipose tissue-derived stem cells for development of wound healing therapies. Int J Mol Sci 18: 1167.

IBRAHIM AH, LI H, AL-RAWI SS, MAJID ASA, AL-HABIB OA, XIA X, MAJID AMA \& JID D. 2017. Angiogenic and wound healing potency of fermented virgin coconut oil: in vitro and in vivo studies. Am J Transl Res 15 9(11): 4936-4944.

KARIM AA, AZLAN A, ISMAIL A, HASHIM P, ABD GANI SS, ZAINUDIN BH \& ABDULLAH NA. 2014. Phenolic composition, antioxidant, anti-wrinkles and tyrosinase inhibitory activities of cocoa pod extract. BMC Complement Altern Med 14: 381.

KELLY KJ \& SUSSMAN G. 2017. Latex allergy: where are we now and how did we get there? J Allerg Clin Immunol 5(5): 1212-1216.

KHANNA S, ROY S, BAGCHI D, BAGCHI M \& SEN CK. 2001. Upregulation of oxidant-induced VEGF expression in cultured keratinocytes by a grape seed proanthocyanidin extract. Free Rad Biol Med 31: 38-42.

KOUTSOUKAS A ET AL. 2011. From in silico target prediction to multi-target drug design: current databases, methods and applications. J Proteomics 74: 2554-2574.

LEONIDAS DD, SHAPIRO R, ALLEN SC, SUBBARAO GV, VELURAJA K \& ACHARYA KR. 1999. Refined crystal structures of native human angiogenin and two active site variants: implications for the unique functional properties of an enzyme involved in neovascularisation during tumor growth. J Mol Biol 285(3): 1209-1233.

LIANG N \& KITTS DD. 2015. Role of chlorogenic acids in controlling oxidative and inflammatory stress conditions. Nutrients 25: 8(1).

LIU X, OUYANG S, YU B, LIU Y, HUANG K, GONG J, ZHENG S, LI Z, LI H \& JIANG H. 2010. PharmMapper server: a web server for potential drug target identification using pharmacophore mapping approach. Nucleic Acids Res 38: W609-W614.

LIVEZEANU C, CRĂIŢOIU MM, MĂNESCU R, MOCANU C \& CRĂITTOIU S. 2011. Angiogenesis in the pathogenesis of pterygium. Rom J Morphol Embryol 52: 837-844.

LODHI S \& SINGHAI AK. 2013. Wound healing effect of flavonoid rich fraction and luteolin isolated from Martynia annua Linn. on streptozotocin induced diabetic rats. Asian Pac J Trop Med 6: 253-259.
MACEDO M \& FERREIRA AR. 2004. Plantas medicinais usadas no tratamento dermatológico da Bacia do alto Paraguai, Mato Grosso. Rev Bras Farmacog 14: 40-44.

MAGALHÃES CS, ALMEIDA DM, BARBOSA HJC \& DARDENNE LE. 2014. A dynamic niching genetic algorithm strategy for docking of highly flexible ligands. Inform Sci 289: 206-224.

MAJEWSKA I \& GENDASZEWSKA-DARMACH E. 2011. Proangiogenic activity of plant extracts in accelerating wound healing: a new face of old phytomedicines. ACTA Biochim Pol 58: 449-460.

MARINHO DG, ALVIANO DS, MATHEUS ME, ALVIANO CS \& FERNANDES PD. 2011. The latex obtained from Hancornia speciosa Gomes possesses anti-inflammatory activity. J Ethnopharmacol 35: 530-537.

MARTINOTTI S \& RANZATO E. 2015. Propolis: A new frontier for wound healing? Burns Trauma 3: 9.

MATOS FJA. 1988. Introdução à fitoquímica experimental. Fortaleza: Edições UFC, 141 p.

MATOS JMD \& MATOS ME. 1989. Farmacognosia. UFC, Fortaleza.

MAY AE, SEIZER P \& GAWAZ M. 2008. Platelets: inflammatory firebugs of vascular walls. Arterioscl Throm Vascular 28 : 5-10.

MELO-REIS PR, ANDRADE LS, SILVA CB, ARAÚJO LMM, PEREIRA MS, MRUÉ F \& CHEN-CHEN L. 2010. Angiogenic activity of Symadenium umbellatum Pax latex. Braz J Biol 70: 189-194.

MOGHADAM SE, EBRAHIMI SN, SALEHI P, MORIDI FARIMANI M, HAMBURGER M \& JABBARZADEH E. 2017. Wound healing potential of chlorogenic acid and myricetin-3-0- $\beta$ rhamnoside isolated from Parrotia persica. Molecules 8: 22(9).

MOURA JM, FERREIRA JF, MARQUES L, HOLGADO L, GRAEFF CFO \& KINOSHITA A. 2014. Comparison of the performance of natural latex membranes prepared with different procedures and PTFE membrane in guided bone regeneration (GBR) in rabbits. J Mat Sci Mat Med 25: 2111-2120.

NETO G \& GUARIM-MORAIS RG. 2003. Medicinal plants resources in the Cerrado of Mato Grosso State, Brazil: a review. Acta Bot Bras 17: 561-584.

NOWAK-SLIWINSKA P, SEGURA T \& IRUELA-ARISPE M. 2014. The chicken chorioallantoic membrane model in biology, medicine and bioengineering. Angiogenesis 17: 779-804.

POTT A \& POTT VJ. 1994. Plantas do pantanal. EMBRAPA, Planaltina, $320 \mathrm{p}$. 
RIBEIRO TP, SOUSA TR, ARRUDA AS, PEIXOTO N, GONÇALVES PJ \& ALMEIDA LM. 2016. Evaluation of cytotoxicity and genotoxicity of Hancornia speciosa latex in Allium cepa root model. Braz J Biol 76(1): 245-249.

RIDIANDRIES A, TAN JTM \& BURSILL CA. 2018. The role of chemokines in wound healing. Int J Mol Sci 18: 19(10).

ROY K, KAR S \& DAS RN. 2015. Understanding the Basics of QSAR for Applications in Pharmaceutical Sciences and Risk Assessment, Chapter 10, p. 357-425.

RUNDHAUG JE. 2005. Matrix metalloproteinases and angiogenesis. J Cel Mol Med 9: 267-285.

SAMPAIO TS \& NOGUEIRA PCL. 2006.Volatile componentes of mangaba fruit (Hancornia speciosa Gomes) at three stages of maturity. Food Chem 95: 606-610.

SÁNCHEZ-MORENO C, LARRAURI JÁ \& SAURA-CALIXTO F. 1998. A procedure to measure the antiradical efficiency of polyphenols. J Sci Food Agric 76: 270-276.

SANDERS MPA, MCGUIRE R, ROUMEN L, ESCH IJP, VLIEG J, KLOMP JPG \& GRAAF C. 2012. From the protein's perspective: the benefits and challenges of protein structure-based pharmacophore modeling. Med Chem Comm 3: 28-38.

SANTOS PO, BARBOSA JUNIOR AM, MÉLO DLFM \& TRINDADE RC, 2007. Investigação da atividade antimicrobiana do látex da mangabeira (Hancornia speciosa Gomes). Rev Bras Pl Med 9: 108-111.

SILVA SMFQ, PINHEIRO SMB, QUEIROZ MVF, PRANCHEVICIUS MC, CASTRO JGD, PERIM MC \& CARREIRO SC. 2012. In vitro activity of crude extracts of two plant species in Cerrado on yeast the Candida spp variety. Ciência \& Saúde Coletiva, 17 (6): 1649-1656.

STAMENKOVIC I. 2003. Extracellular matrix remodelling: the role of matrix metalloproteinases. J Pathol 200(4): 448-464.

SUN Q, HEILMANN J \& KONIG B. 2015. Natural phenolic metabolites with anti-angiogenic properties - a review from the chemical point of view. Beilstein J Org Chem 11: 249-264.

WALLACE HA \& BHIMJI SS. 2017. Wound, Healing, Phases. [Updated 2017 Nov 26]. In: StatPearls [Internet]. Treasure Island (FL): StatPearls Publishing; 2017 Jun. Available from: https://www.ncbi.nlm.nih.gov/books/NBK470443/.

WITTENAUER J, MACKLE S, SUSSMANN D, SCHWEIGGERT-WEISZ U \& CARLE R. 2015. Inhibitory effects of polyphenols from grape pomace extract on collagenase and elastase activity. Fitoterapia 101: 179-187.
XUE M \& JACKSON CJ. 2015. Extracellular matrix reorganization during wound healing and its impact on abnormal scarring. Adv Wound Care 4(3): 119-136.

\section{How to cite}

D'ABADIA PL, BAILÃO EFLC, LINO JÚNIOR RS, OLIVEIRA MG, SILVA VB, OLIVEIRA LAR, CONCEIÇÃO EC, MELO-REIS PR, BORGES LL, GONÇALVES PJ \& ALMEIDA LM. 2020. Hancornia speciosa serum fraction latex stimulates the angiogenesis and extracellular matrix remodeling processes. An Acad Bras Cienc 92: e20190107. DOI .

Manuscript received on January 30, 2019;

accepted for publication on May 3, 2019

PATRÍCIA L. D'ABADIA'

https://orcid.org/0000-0003-4756-4869

\section{ELISA FLÁVIA LUIZ C. BAILÃO ${ }^{1}$}

https://orcid.org/0000-0001-6737-7548

\section{RUY S. LINO JÚNIOR}

https://orcid.org/0000-0002-0572-5102

\section{MATHEUS GABRIEL OLIVEIRA ${ }^{3}$}

https://orcid.org/0000-0003-0692-9729

\section{VINICIUS B. SILVA 3}

https://orcid.org/0000-0002-5066-7431

\section{LEANDRA A.R. OLIVEIRA ${ }^{4}$}

https://orcid.org/0000-0002-7278-038X

EDEMILSON C. CONCEIÇÃO ${ }^{4}$

https://orcid.org/0000-0003-4113-2686

\section{PAULO ROBERTO MELO-REIS ${ }^{5}$}

https://orcid.org/0000-0001-9660-2572

\section{LEONARDO LUIZ BORGES ${ }^{1}$}

https://orcid.org/0000-0003-2183-3944

\section{PABLO JOSÉ GONÇALVES ${ }^{6}$}

https://orcid.org/0000-0003-0246-1073

\section{LUCIANE M. ALMEIDA ${ }^{1}$}

https://orcid.org/0000-0003-1764-1480

'Universidade Estadual de Goiás, Rodovia BR 153, no 3105, Fazenda Barreiro do Meio, Campus Henrique Santillo, 75132-400 Anápolis, GO, Brazil

${ }^{2}$ Universidade Federal de Goiás, Instituto de Patologia Tropical e Saúde Pública, Rua 235, s/n, Setor Leste Universitário, 74605-050 Goiânia, GO, Brazil 
${ }^{3}$ Pontifícia Universidade Católica de Goiás, Escola de Ciências Médicas, Farmacêuticas e Biomédicas, Av. Universitária, n

1069, Setor Leste Universitário, 74605-010 Goiânia, GO, Brazil

${ }^{4}$ Universidade Federal de Goiás, Laboratório de

Pesquisa, Desenvolvimento \& Inovação de Bioprodutos, Faculdade de Farmácia, Rua 240, s/n, Setor Leste

Universitário, 74605-170 Goiânia, GO, Brazil

${ }^{5}$ Pontifícia Universidade Católica de Goiás, Laboratório de Estudos Experimentais e Biotecnológicos, Rua 232, no 128,

Setor Leste Universitário, 74605-120 Goiânia, GO, Brazil

${ }^{6}$ Universidade Federal de Goiás, Instituto de

Física, Av. Esperança, s/n, Campus Samambaia,

74690-900 Goiânia, GO, Brazil

Correspondence to: Luciane Madureira de Almeida

E-mail:almeidalm@hotmail.com, luciane.almeida@ueg.br

\section{Author contributions}

All the authors declare to have made substantial contributions to the article conception. LMA, PJG, EFLCB are mainly responsible for the conception, design, analysis and writing of the article. PLA, RSLJ, MGO, LARD, PRMR and LLB are mainly responsible for the acquisition, analysis and interpretation of data. ECC and VBS made critically revising of the intellectual content. Finally, all authors approve the version to be published.

\section{(c) BY}

